\title{
PROMOTING READING CONFERENCE AS AN EFFECTIVE TECHNIQUE IN TEACHING READING OF EFL LEARNERS
}

\author{
Khoiriyah \\ Nusantara PGRI Kediri University \\ khoir.khoiriyah@yahoo.co.id
}

\begin{abstract}
This study examines the effectiveness of reading conference technique in teaching reading of EFL learners. Thirty two learners consisting of 12 males and 20 females from the second grade of English Department at Nusantara PGRI Kediri University were participated in the study. To conduct the study, pre-test were administered before applying treatment, while post-test were administered after applying treatment. Quantitative method and pre-experimental approach were applied in this present study and t- test was used to analyze the data. The analyses resulted in the finding that the score of post-test exhibited significantly better than the score of pre-test. Thus, it can be said that reading conference is effective in teaching reading at the second grade learners of English Department at Nusantara PGRI Kediri University.
\end{abstract}

Keywords : effective, reading comprehension, reading conference technique

\section{Introduction}

Reading, which is one of the four language skills, can be classified into two types; initial reading and reading comprehension. Initial reading is an effort made by those who have not been able to read to learn reading (e.g., how to read the alphabet and combination of letters or simple words), whereas reading comprehension is an activity aimed to understand the messages of a particular text (Williams, 1998 in Cahyono and Widiati, 2006). Thus, it can be said that reading deals with understanding written text. The teaching of reading as a foreign language (EFL reading) can be generally included in teaching of reading comprehension because the goal is to enhance the learners' skills in comprehending the meaning of written text. Although it is actually a complex activity involving both perception and thought, it is an everyday activity done by learners not only in the classroom but also out of the classroom. For instance: they read newspapers, magazines, novels, bills, advertisements, menus, prices and fares, notices, manuals, schedules, announcements, invitations, forms, articles, books, etc. It is supported by Mikulecky $(2008: 1)$ that reading is a conscious and unconscious thinking process. The reader applies many strategies to reconstruct the meaning that the author is assumed to have intended. The reader does this by comparing information in the text to 
his or her background knowledge and prior experience.

In fact, many daily activities are linked with reading and everyone cannot afford not to read on single day. Thus, having good reading proficiency is necessary for learners. Moreover, in reading the readers interact with the writer to comprehend the writer's ideas. Weir and Singhal in Seken (2004) state reading comprehension is basically an interactive process of meaning making between the reader and the author through the text, which involves mental activities and background knowledge. Thus, by reading various literature, the learners can gain information, knowledge or to establish existing knowledge and build their vocabulary.

Getting learners to read English texts is an important part of the English teacher's job because of many reasons. First, many students want and need to be able to read English texts for study purposes, for future career or simply for pleasure. Second, the more students read, the better readers they become. Third, reading text provide good models for English writing, concerning construction of phrases, sentences, paragraphs and whole text. The last, good reading texts can introduce interesting topics, stimulate discussions, excite creative responses, and provide trigger or springboard for wellrounded, fascinating lessons (Hamer, 1998:67) .
In teaching learning process, the learners should be able to read the text to gain some information what they have been read and also followed by answering the questions given. To reach this goal, the learners should use reading strategies. Although reading is considered to be an important language skill, many learners are likely to be reluctant EFL readers (Kweldju, 2000) and EFL reading is commonly seen by university students as an uninteresting activity (Firmanto, 2005; Kweldju, 1996; Rukmini, 2004 in Cahyono and Utami, 2006). In her study of English department students' interest in reading, Kweldju (1996) found that the students were not interested in reading their content area textbooks although they thought such textbook were useful. She stated that the reason behind this lack of interest included students' limited background knowledge, inability to understand the content of text, and complicated organizational structure of text. In Firmanto's survey on what students do and expect when reading, Firmanto (2005) found that reading was considered a boring and stressful activity because of some factors such as unsuitable texts (e.g., due to the text length or unfamiliar vocabularies), teachers' scarcity in employing pre-reading activities (e.g., explaining some difficult words or activating the students' prior knowledge), and monotonous post-reading activities (e.g., answering questions based on the texts and retelling texts). 
In fact, many learners of second grade of English department at Nusantara PGRI Kediri University are reluctant and unmotivated to read EFL reading and think reading is stressful and monotonous activity. So, they only read the text that has been given to them and they do not use an appropriate reading strategy during reading. Thus, they get some difficulties in reading comprehension and they cannot answer the questions well such as: finding literal, inferential, and critical comprehension, for instance: they do not understand to find an important information stated in the text; find the topic, main idea, and content of text; find implied information; and they do not know the meaning of some words in the text. Thus, the lecturer should help the learners to change their inefficient reading habits and to avoid their indolence by teaching them using an appropriate reading technique to make them interested and motivated to read EFL reading materials.

Out of the problems above, this research applies reading conference as one of technique in teaching reading to help the learners in understanding the text that they have read. Reading conference is a kind of conversation between the lecturer and the students to share or talk about what they have read. It is in line with this statement that reading conference is a brief discussion with an individual child or small group of children. The conference may occur before, during or after independent reading take place. Here, the lecturer will need to device a record system which suits her/his needs (see reading comprehension questions) a relaxed setting such as conference table or carpeted area (Houghton Mifflin, 1993). Moreover, reading conferences can be used for both assessment and instruction. The conferences should be kept brief and focused. The teacher can select two to three students with whom to hold a reading conference each day (Ontario, 2005: 6). In addition, Jeffries and Mikulecky (2005: 21) state that reading conference is one-onone conversation about the students' book with the other. By reading conference, the lecturer may ask various questions about expressive, factual, summarizing, sequential, predictive, experiential, critical, inferential, affective, etc. From students' answers, it is usually easy to tell if they have read the book or other material and how well they have comprehended what they have read. During reading conference, the lecturer can help the learners express their ideas. The important thing is for learners to gain confidence in their ability to communicate their reaction to their reading.

\section{Method}

The research design of this study was quantitative method and pre-experimental approach using One-Group Pretest-Post Design because it was intended to know the effectiveness of reading conference in teaching reading. The subjects were 32 
learners of the second grade of English Department at Nusantara PGRI Kediri University in academic year 2013/2014 consisting of 12 males and 20 females. The choice of accessible subjects is under a certain consideration that they have studied English since they were in Junior High School for at least eight years. So, they were assumed to have enough experience in learning English in term of language skills and language components.

Reading comprehension test was employed to collect the required data. The researcher used simple random sampling in determining the sample. The test was given in the form of pre-test and post-test. Pre-test was employed before treatment. Then giving treatment to samples by teaching reading using reading conference technique. After that, post-test was employed to assess the results of the treatment. To know the difference between the average score of pre-test and post-test, ttest formula was used to analyze the data.

\section{Result}

The result of learners' reading comprehension before and after being taught using reading conference technique showed that the total score of pre-test was 1925 out of 32 participants. So, the mean of pre-test was 60. 2. While the total score of post-test was 2199 and the mean of post-test is 68. 7. It means that the mean of post-test score was higher than the mean of pre-test. It can be seen in table 1.

Table 1.

Average Score between Pre-test and Post-test

\begin{tabular}{|l|l|l|}
\hline $\begin{array}{l}\mathrm{N}=32 \\
\text { students }\end{array}$ & Pre-test & $\begin{array}{l}\text { Post- } \\
\text { test }\end{array}$ \\
\hline $\begin{array}{l}\text { Total score } \\
\text { Mean }\end{array}$ & 1925 & 2199 \\
60.2 & 68.7 \\
\hline
\end{tabular}

In addition, the score different of pre-testpost-test showed that the total score of pre-test was 1925, and then total score of post-test was 2199. It means that student's score of post-test was increased. The minimum of $\mathrm{D}$ (total scoring of posttest-pretest) was 274 and the final result of ${ }^{\mathrm{D}^{2}}$ was 6302 .

Out of the result above, it can be seen that the mean different of pre-test and post-test score were 8 . 56. While calculation of the number of standard deviation score was 3955. 9. Furthermore, the result of calculating t-test was 4.28 and the degree of freedom (db) was 31. It means that Reading Conference is effective to teach reading comprehension. It can be seen from the table of differences level of significant from t-table and t-score below.

Table 2.

The differences level of significant from $\mathrm{t}$ table and t-score

\begin{tabular}{|c|c|c|c|c|c|}
\hline \multirow[b]{2}{*}{$\mathrm{Db}$} & \multirow[b]{2}{*}{ t-score } & \multicolumn{2}{|l|}{ t-table } & \multirow{2}{*}{$\begin{array}{l}\text { Signific } \\
\text { ant }\end{array}$} & \multirow[b]{2}{*}{ Ho } \\
\hline & & $\begin{array}{l}1 \% \\
(0.01)\end{array}$ & $\begin{array}{l}5 \% \\
(0.05)\end{array}$ & & \\
\hline 31 & 4.28 & 2.750 & 2.042 & $\begin{array}{l}\text { Signific } \\
\text { ant }\end{array}$ & $\begin{array}{l}\text { Reject } \\
\text { ed }\end{array}$ \\
\hline
\end{tabular}


Based on the table above, the result of this research shows that t-score is 4.28 at the degree of freedom 31 and t-table is 2.042 at the level of significance of 5\% (0.05) and 2. 750 at the level of significance of $1 \%(0.01)$. It means that t-score (4. 28) > t-table at the level of significance 5\% (2.042).

The data showed that $\mathrm{t}$-score is higher that $\mathrm{t}$-table in the significance $5 \%$. Therefore, the alternative hypothesis ( $\mathrm{Ha})$ is accepted and (Ho) is rejected. It can be concluded that Reading Conference is effective to teach reading at the second grade learners of English Department at Nusantara PGRI Kediri University.

\section{Discussion}

The result indicated that Reading Conference technique is effective to teach reading at the second grade learners of English Department at Nusantara PGRI Kediri University as EFL learners. Comparing pretest and post-test mean scores, reading conference technique assisted reading comprehension of learners. Moreover, there was a significant difference between pre-test and post-test scores after instruction. It is in line with the previous research on using reading conference technique to improve reading comprehension achievement, it is found that reading conference can effectively improve students' reading comprehension. Reading conference can help them understand a lot in learning English reading. The students like to use reading conference as it was really helpful in studying especially to improve their reading comprehension achievement (Kurniawansah, 2012). Similar to the previous research, the present study has reaffirmed the effectiveness of reading conference technique on enhancing learners' reading performance. The positive effects are evident in post-test. It has also shown that this technique can be effectively implemented in a regular EFL classroom setting.

The present study has shown that the second grade learners of English Department at Nusantara PGRI Kediri University as EFL learners made progress after being taught using reading conference. The statistical evidence lends its support to the positive effect of reading conference on enhancing learners' reading performance. Indeed, they gained significantly higher scores after receiving instruction through this technique. Bergeron and Melody (2002: 151) say that, "Ongoing conferencing is essential for keeping a close watch on students' progress and for providing the right subsequent lessons at the opportune time...".

Reading conference technique gives contribution to the second grade learners of English Department at Nusantara PGRI Kediri University. First, reading conference can create a relaxed an atmosphere so that learners will express their feeling about reading or comment on the kinds of books they enjoy. Second, they can enjoy and feel confidence in 
reading because they are allowed to choose the material based on their level and interest. Third, they get easier to comprehend what they have read, such as: finding literal, inferential, and critical comprehension, for instance: they understand to find an important information stated in the text, find topic, main idea and content of text, find implied information, they know the meaning of some words in the text. Finally, they can know their strength and weakness in reading because the lecturer gives them attention intensively.

\section{Conclusion}

The present study has evaluated the effectiveness of reading conference technique to teach reading comprehension at the second grade learners of English Department at Nusantara PGRI Kediri University as EFL learners. It is found that reading conference was one of effective technique in teaching reading of EFL learners and significantly enhanced the learners' reading comprehension.

$$
\text { Reading conference is really }
$$
appropriate technique in teaching reading of EFL learners so that the learners are interested to the material and also it can arouse the learners' motivation in studying reading comprehension. By using reading conference, learners will enjoy and feel confidence in EFL reading. They will also concentrate while reading and try to understand the material easily. This technique will help learners to comprehend what they have read based on background knowledge and experience. In short, reading conference effects the learners' reading comprehension of the second grade of English department at Nusantara PGRI Kediri University.

\section{Acknowledgments}

I am grateful to anonymous reviewer whose insightful comments on the earlier draft of this manuscript were invaluable. My special thanks goes to second grade learners of English department who have participated in this study.

\section{References}

Bergeron, Bette and Melody Bradbury-Wolff. 2002. Teaching Reading Strategies in the Primary Grades. Scholastic.

Cahyono, B.Y.and Utami,W. 2006. "TheTeaching of EFL Reading in the Indonesian Context: The State of the Art". TEFLIN JOURNAL. Vol 17, No.1. pp 36-58.

Harmer, Jeremy.1998. How to Teach English. New York: Longman.

Kurniawansah, A. 2012. Using Reading Conference Technique to Improve Reading Comprehension Achievement of the Eight Grade Students at Junior High School Number 9 Palembang. Theses. Unpublished. Sriwijaya University.

Milkukecy, Beatrice.S .2008. Teaching Reading in a Second Language. Rusia: Pearson Education, Inc.

Mifflin, H. 1993. Reading Conference. Houghton Company. 
Mikulecky, B. S. and Jeffries, L. 2005. Advanced Reading Power. White Plains: Pearson Education, Inc.

Ontario. 2005. Independent ReadingAssessment Tools. Queen's Printer.
Seken, I Ketut. 2004. "Developing a Cloze Procedure as a Reading Comprehension Achievement Test". TEFLIN JOURNAL. Vol. 15., No.2. 